\title{
Becoming Fluent in Fieldwork: (Un)learning What Is Good/Ethical/Responsible Fieldwork
}

\author{
Birgit Poopuu \\ School of Governance, Law and Society, Tallinn University, Tallinn, Estonia \\ Karijn van den Berg \\ Institute for Interdisciplinary Studies, University of Amsterdam, Amsterdam, \\ The Netherlands \\ k.vandenberg@uva.nl
}

\begin{abstract}
This running theme's introduction rethinks fieldwork as an ongoing process. It explores experiences and conceptions of 'becoming fluent in fieldwork': the contextual processes through which we do, learn, and unlearn practices of fieldwork. It sees fieldwork as a collective project. Recognising the entanglement of field sites and travelling with fields to certain other fields, we become multiply entangled, and thus we ask: what do these plural relations demand from us? We turn to the concept and praxis of love as it considers the responsibility, care work and thinking-working together that is needed to respect other people's realities together with them. We foreground the notion of 'becoming fluent' that reflects fieldwork as a work in process, and emphasises the processual aspects of fieldwork: the journey that spans the time before, during and after the fieldwork. This process involves engaging meaningfully with relations, relationality and collaboration, 'ongoingness' and ethics in motion.
\end{abstract}

\section{Keywords}

becoming fluent - love - relations and relationality - ongoingness - collaboration ethics in motion 


\section{Introduction}

It was in Aberystwyth at the International Politics department where we started working together. We arrived at this running theme by having ongoing conversations about fieldwork, setting up a 'fieldwork chats' group, organising a workshop on fieldwork, discussing our ideas as a collective at a conference - that is, ruminating on fieldwork as an ongoing praxis, a process of becoming. In this introduction to the running theme we collectively reflect on how this collection came about, how sharing our fieldwork experiences stretched our imaginations about the constant work that needs to go into ethical knowledge encounters, and how we propose the concept of 'becoming fluent in fieldwork' as way to equip ourselves better for future fieldwork encounters. These discussions are laced with narratives from our 'fields' and snapshots from our contributors' pieces.

At the start of the academic year (October 2018) Birgit organised a workshop together with a colleague that involved a live-stream event from Turku, Finland on 'Failure, Secondary Trauma \& Self-Care in Field-Based Social Research'. We were in a cold and dark room, with only a small group because gam time slots were not exactly popular amongst $\mathrm{PhD}$ students. As we encountered technical difficulties getting the livestream to work, we found ourselves having interesting chats in between, when the live stream broke off. Some mentioned their own ethical dilemmas in the field, or some anxieties and difficulties they had run into. These conversations were almost more interesting and engaging than the livestream that had brought us together in the room. This led the two of us to come up with a 'fieldwork chats group', where we could more explicitly share some of the personal experiences with fieldwork that had come up in the workshop. In monthly 'fieldwork chats' we gathered with a small group in a café on campus, discussing our fieldwork practice, sometimes texts that spoke to puzzles that animated our experience, ethical dilemmas and our own positionalities in our respective fields. These conversations felt really rich to us and seemed to raise even more questions that we could not figure out. We felt grateful for the group but also frustrated that so many of the dilemmas and questions that we faced during our fieldwork were not dealt with in our textbooks nor in our methodological training. It occurred to all of us that there is something about fieldwork that can never really be learned'.

At the same time, however, by noticing and voicing this together in conversation, rather than being frustrated by this individually, we actually seemed to be learning a lot. This experience led us to organise a workshop in the Summer of 2019 that brought together different early career scholars. We discussed what the messy process of fieldwork entails, and how we train ourselves by doing, but also by sharing with peers about the process. Together, we shared our stories of unease about how we practice fieldwork. We felt that what we are doing 
when we 'do' fieldwork does not follow a neat, linear path that has a concrete endpoint. Rather, we came to see that there exists a quality of ongoingness in doing fieldwork. And so, we came to realise that we were dealing with something that is a travelling concept and mode of work. Through our multiple conversations we learned that this here - us ruminating on how we do fieldwork and why we make certain moves - is fieldwork. It was fieldwork in a sense of re-ordering, only if ever so slightly, the scaffold of our disciplinary house that seemed to push us to go and do our fieldwork someplace else and then come back and talk about it. We felt that talking about our fieldwork here, with the academic straight-jackets that we experience as being pulled over our heads, ${ }^{1}$ is a chance to co-imagine a journey that is different. ${ }^{2}$ If our methods together with the research routes provided by our academic homes imagine worlds, and we thus participate in building worlds, what is our responsibility? Do we need to re-imagine our identities, perhaps as 'scholar-activists', to make our practice part of wider struggles and structures of injustice? Is this even possible? ${ }^{3}$

Karijn on scholar-activism: For me it was difficult to negotiate, before (when trying to establish some contacts), during, and after my fieldwork how I should position myself. I wanted to be honest and transparent about my position as a researcher but also wanted to express the ways in which I felt solidarity with the activists I was working with and interviewing. Still, showing up as an 'activist' to my field sites also did not feel truthful. As I was immersing myself deeper and

1 For example, this speaks to the (felt) expectation that research must come with clear-cut findings and certainty for it to be 'rigorous research'. This can make us feel like there is no room for ambiguity in our findings and only limited time for 'figuring things out'. But what if we let such ambiguity and figuring out take centre stage - following Lisle's 'happy wrecks' positionality - in our research practice and reporting? Would it potentially lessen the grip of anxiety to present 'polished research outcomes' and could it make our research and our world(s) more open to alternative stories?

2 This also means coming to terms with the everyday ways in which we strive to move against, re-imagine 'the fast-paced, metric-oriented neoliberal university' (Mountz et al. 2015, 1235), yet nevertheless continue, as we are part of it, to exist in its structures, to be complicit in its violence (this simultaneous sentiment of neoliberal pain and critique is aptly captured by Kurowska 2020b). We have more starting points available to us now: so can we in our academic homes re-imagine our disciplines in anti-colonial ways, through our syllabi, how we teach, what we research and how (Rutazibwa 2020)?

3 We do not even pretend to be able to answer this question, but we have registered that certain commitments and ways of seeing the world, e.g., revolutionary feminism (Bhandar and Ziadah 2020; Lowe 2020) demand from us more active engagement with the world (Olufemi 2020). Equally, being aware that our research methods do not just see worlds but also actively imagine worlds, see Aradau and Huysmans (2014), calls on us to seriously re-think what constitutes ethical research, see Poets (2020). For a detailed practice-near account of what scholar activism entails, see Chatterton, Hodkinson, and Pickerill (2010). 
deeper into academia by way of the PhD, I also became unsure myself whether I even wanted to make a claim being an activist. Although earlier in my career, still in my MA, I had been so inspired by peers, teachers, and even activists I interviewed back then ${ }^{4}$ to use the term 'scholar-activist'. More and more, as I simultaneously occupied myself with activism and political issues but also further entered academia, the term of scholar-activist became less sensical to me: if we truly want to express a modular or bridging identity and position, then how come it is academics that claim this identity label, whereas activists are always simply 'activists'? Should I even be worrying myself about these different labels and positions, when in the end this was precisely what was under question in my research, where activism is a plural and not taken for granted notion? Although I wanted to open definitions, I still felt, as I entered my fields, that my own notions of activist and academic imposed themselves on me: as I travelled on a bus with activists going to a direct action I sure looked a little out of place when we arrived at a big campsite, everyone walking around with their backpacks in the muddy field except for me: hesitatingly trotting around with my trolley case and laptop. But during my fieldwork it turned out that the boundaries and definitions of what activism, or 'an activist' is, is also open to many who practice various forms of political organising. Some started to question the term activist, others did not want to label themselves as such, worrying that they would become seen as gatekeepers of 'activism', rather than keeping political action open and inclusive. These outcomes of my encounters got me wondering what even 'our' role is as researchers in theorizing and writing about social problems, and whether laying claim to or putting expectations on ourselves of being an 'activist' isn't unnecessarily making things difficult for ourselves. Going through this process, negotiating these different positionalities (activist, researcher, activist-scholar) and the connotations they carry, has brought me to a seemingly un-exciting end point so far. I make no illusions that the academic work I undertake is 'activism,' or has activist potential. Still, I have come to learn and negotiate some of these tensions - and my own discomfort that comes with being a 'researcher' in 'activist' spaces - by recognizing that I can make certain research and fieldwork decisions that are political. What do I write about and how? Who do I talk to, to be able to do so? I now understand that walking with such questions 5 will be an ongoing part of my research journey and my journey as a researcher.

4 Karijn: My MA research focused on aligning theory and practice of feminism and environmentalism through the personal accounts of members of La Via Campesina, a transnational peasant movement.

5 The expression of 'walking with questions' is inspired by the Indigenous Zapatistas in Mexico and their saying 'Preguntando caminamos' ('while asking questions, we walk'). The journey and next steps will evolve, even as I negotiate, ponder and stay with these questions and the answers may never be definite. 
Conceptually, this running theme delves into different experiences and conceptions of 'becoming fluent in fieldwork': the contextual process in which we do, learn, and unlearn practices of fieldwork. By foregrounding the processual nature of becoming fluent - rather than fluency - the running theme highlights how fieldwork is rarely something chosen and applied (in a linear way) but rather something that is in constant flux. By doing so we problematise mainstream and static takes on fieldwork, underlining instead the processual and messy nature of fieldwork (Carabelli and Deiana 2019; Eliasoph 2005; Fobear 2016; Kurowska 2020a; Kušić and Zahora 2020). Becoming fluent in fieldwork in this sense entails developing reflexive expertise: it is a process of continuous (un)learning, figuring out, of negotiating working with research participants/ associates, of making mistakes - a balancing act between the planned and the unplanned (Cerwonka and Malkki 2007; Goffman 2014). We have invited contributions to ruminate on this process of becoming a field researcher and how our institutional and, relatedly, perceived personal 'fields' influence what spaces come to count as 'fields'. The collection thus illustrates the myriad entanglements through which fieldworkers continuously space the field, and engages with how 'the field' emerges as a critical site of knowledge production that is never static or bounded, but always in process.

In a way this approach - the entanglement of field sites and travelling with fields to certain other fields - is not particularly new, but we felt that we needed to explore it and invite others to embark on this journey with us. Because we see that in addition to individually thinking through your practice, this needs to be a collective project as the scaffold around fieldwork needs to change too (see Mountz et al. 2015; and esp. Evans, Hughes and Potts 2021). Critically, we maintain that fieldwork is not only a continuous journey but also one in communion, hence we believe that the process of sharing and learning must be front and centre. ${ }^{6}$ Precisely because fieldwork can at times feel like an individual or lonely endeavour, riddled with anxieties and navigating ethical dilemmas and other difficulties, we believe it is vital to think through our fieldwork with friends, peers and colleagues. ${ }^{7}$ That is why we owe a sincere thanks to

6 A methodology of unease that Eriksson Baaz and Stern (2016) arrive at in the course of their research animates our thinking, and we are grateful for these scholars for sharing their experience of what it means to walk around with unease while in the midst of your research and to have the courage to write about it (similarly, work that shows rather than denies our humanness, our interdependence and vulnerability is captured in Kušić and Zahora 2020).

7 Questions surrounding researcher's wellbeing are usually not addressed by institutional ethics guidelines, making self-care and readiness to cope with stressful situations a personal matter. Thus, many researchers feel utterly unprepared when they are confronted with difficulties in the field. The wider dynamics, issues and suggestions around self-care and wellbeing are 
feminist thought that has introduced us to practices of how to work together - in communion (hooks 2002) - when grappling with puzzles; how to practice change so that it shakes us up and causes ripples to think and do differently, in a way that actively imagines the world in a more just way (Olufemi 2020).

Dwelling very briefly on communion - and the connected ideas of allyship and slow scholarship - and feminist solidarity work (Berg and Seeber 2016; hooks 2002; Causevic et al. 2020; Mountz et al. 2015; Olufemi 2020), it is critical for us to centre another word - love - that does not often find its way into the texts we consume and script ourselves in. But it is so pivotal, because it holds much-needed self and communal care - 'love involves the acknowledgement of the reality of other people' (Pin-Fat 2019, 200). We need to continuously work to not just become fluent in fieldwork, but to become caring and responsible researchers (Fujii 2017) by listening to and learning from others, building solidarity, sharing, and fostering respectful relationships. Building our praxis around hooks' communion (2002) and Olufemi's feminist solidarity work (2020) means that we have been building respectful relationships together and around us, including thinking on how we not only work and support each other but also listen to and support those around us. In this way, our ideas around becoming fluent in fieldwork started with many experiments of doing together.

The concept and practice of love creates the needed space for communion, for care work that goes beyond the self and stitches together the different spaces: asking us to think of people in relation to one another and consequently in relation to the different 'fields' we carry with us and move to. In this way, love is a political concept and practice (see Berlant 2011). Love asks us to consider the responsibility (or 'response ability' with Haraway), care work and thinking-working together that is needed to acknowledge, as Pin-Fat says, the reality of other people together with them. ${ }^{8}$ It is with this acknowledgement of deep entanglement between our lives and worlds that we can think with and practice the concept of love. In this way, throughout our Introduction and our contributors' pieces we centre fieldwork as a collective project and what this demands from us. Working through practices of love, care and communion both slows us down and alerts us to the responsibilities we have towards one another, allowing for more contextual figuring out to be done together in

addressed in the special issue The Cost of Bearing Witness: Secondary Trauma and Self-Care in Fieldwork-Based Social Research (see Močnik and Ghouri 2020).

8 We are also heavily inspired here by the work and thinking of Mariame Kaba and her notions of interconnectedness needed for challenging oppressive structures and bringing new worlds and narratives into being (see Ewing 2019). 
different configurations along the way. More importantly, it helps us in facing struggles ahead while not offering respite from the rich social fabric we are working with. Given this, we found that Debbie Lisle's 'happy wrecks' positionality is useful: it openly centres the sheer ambiguity we are working with and crafts a way to stay with it rather than to deny it. Thus, inhabiting a position of 'happy wrecks' (Lisle 2016) by letting go of certainties, we went without a concept on the horizon but were led by our mutual desire to work together towards a fieldwork and research praxis that is unpacked in collaboration.

'How to do fieldwork' for us became focussed on saying that it is a collectively continued exploration. It is an attempt to continuously work at our practice of doing ethical-responsible research. It is a realisation that 'given that our "selves" are constructed by our social relations, we cannot have complete or transparent access' (Dauphinée and Ravecca 2018, 6; Kurowska 2019, 81); we are always ongoingly muddling through our fieldwork as the exact encounters shake us, sometimes trouble us, make us see different things, differently, and always mirror our academic and personal encounters that feed into our navigations with(in) multiple fields. In these encounters, we are also inevitably affected by our academic fields.

Both of us, and we together, have had experiences of lectures and talks by peers, colleagues or those higher up the academic ladder that have reinforced academic status quos. This has meant, for instance, sitting through numerous talks where the speakers unabashedly enact a familiar act of what Lily Ling (2017) calls Hypermasculine-Eurocentric Whiteness (HEW). So, at close range, we have seen exclusive/colonial knowledge in action: suggesting that gender, race and empire are not relevant for IR because they do not speak to what is called the core problematique of IR (anarchy, survival, security dilemma). Somehow, for the speaker, what the core problematique is has been so self-evident, unquestionable, and normal that the pain in committing violence to whole groups of people remains with us and the speaker gets away with basing his whole argument on the 'tremendous power of White world sustained amnesia and erasure' (Rutazibwa 2020, 231). When these speakers are challenged, and they usually are, they commit erasure again and again. ${ }^{9}$

Even if our fields are fractured and today entail so much more than the above example shows, the HEW' mentality aligns with the much broader issue that 'universities around the world exist to reproduce coloniality and neoliberal capitalism'

9 For instance, in one of these talks, a $\mathrm{PhD}$ student during the Q\&A points to the vast Eurocentrism that has been at the heart of IR, the speaker belittles and dismisses Eurocentrism as a term, asking what the point of that term is if it just refers to the world as it is, reducing it to a sociological fact. 
(Kamola 2020, 19). So, the space where we speak from, even if critically, continues to plunder the world we study. Owing to this, we/those (of us) in academia need to get beyond critique and 'transform the social relations that make [our] discipline possible' (ibid., 21). If our disciplines and our universities make some imaginaries and worlds more possible than others, if our research participants point to the continuum of violence that extends to us, and the ways we understand, we need to engage in change work at home (some good strategies of how to do this are captured in Kamola's work 2020, 21-26).

It is only recently that more experience-near accounts of fieldwork have become a reality (Bliesemann de Guevara and Bøås 2020; Daigle 2015; Günel, Varma and Watanabe 2020; Mac Ginty, Vogel and Brett 2020; Kaczmarska 2020; Kurowska 2020a; Kušić and Zahora 2020; Perera 2017; Wilkinson 2015) that our anxieties and questions feel more recognised, heard, perhaps answered, but most importantly leaving room for further debate. We wanted to find out what happens if we carry this unease with us (rather than suppress it), if we talk and work through it honestly and with an eye to our own and our peers' experiences and practices. Reflecting on such questions, Kušić and Zahora (2020) argue that there are two phases of fieldwork-based projects which are usually marked by failures: being in the field and writing up. Our running theme further stretches this imaginary by reflecting on fieldwork as a learning process, which for us has indicated that the preparation for and the aftermath of it need to be included in our conversations. Thus, becoming fluent means learning, negotiating, figuring out what, why, and how to do fieldwork every step of the way. Experimentations and reflections are essential.

Rather than proposing a definition of 'fieldwork fluency' or proposing a guideline or blueprint of how fieldwork fluency can be achieved, we want to foreground a notion of 'becoming fluent' that reflects fieldwork as a work in process (not progress). We emphasise the notion of process to highlight what to us are the more interesting aspects of fieldwork: the journey in itself that spans the time before, during and after the fieldwork, rather than fieldwork fluency as an end station. Still, without giving a neat definition, we propose that fieldwork fluency carries certain components: relations, relationality and collaboration, 'ongoingness' and ethics in motion. We have grouped together the notions of relations-relationality and collaboration: where the first term 'relations-relationality' considers the spaces and relations we hold throughout our fieldwork processes; and 'collaboration' carefully thinks through where and with whom we start our research and how we work and think with others throughout the research. Of the last two concepts, 'ongoingness' imagines fieldwork as a process and thus asks: what are our responsibilities in different spaces? What is the work we need to do in our academic homes? Finally, 
'ethics in motion' explores what a deeply contextual figuring out looks like. We will now dwell on each of these components briefly to reflect on their role in the fieldwork process, as well as how these notions impact more dominant takes on what fieldwork is or what it should look like. As this running theme collective worked collaboratively, the mentioned themes visibilised only at a later stage when we had a chance to read and comment on each other's work. We noticed that many works speak to multiple themes and thus the themes stretch and spill over. Owing to that, we do not offer neat stand-alone thematic groups but let our contributors speak across them.

\section{Relations and relationality}

Birgit: One day in April 2019 while I was doing my fieldwork interviews in Beirut, I accidentally came across a large piece of artwork that caught my eye when I was looking for the bathroom in a café I happened to be in. The piece of art hung on the ground-floor wall of a café, in dim-lighting and a slightly compressed setting, the ceiling accommodated shorter people like myself (or so I remember it). The piece, in solitude on one wall, seemed enormous; it was provocative in its use of colourful fabric wrapped around what seemed motionless bodies. For me, its hold on the world was so strong, because it was capturing in broad strokes how the world operates: the everyday politics of deciding whose lives matter and whose don't. I stood and stared at the light brown, rough and rugged cloth (كفن; kafn or shroud) on which countless dead bodies were wrapped in colourful cloth. I thought about this as a memorial that speaks to and conveys so many people's truth (and I wondered who else has stood, stared and interpreted). Later, as I asked about the author of this work, I found out that it was a Syrian artist. And unlike me, reading a lot of heaviness into it, he made it by tapping into his emotions on that particular day, and while it was true that it was made in the honour of Syrian people, the piece of art was thought of and made to capture life and hope rather than just (or mainly) death. As the artist expresses their general modus vivendi: 'what I would like to do, is not about violence, rather, what is behind it: hope, dreams ... I don't believe in reality, realistic people don't build the future, they live in caves' (Personal communication 30 April 2019).

I found out the author's thoughts when I contacted them just to express my gratitude for being able to see the artwork. I asked if they have any other work that is accessible. They sent me a link to a web page that featured their work. We started talking and I ended up asking if they were up for a conversation. We don't always have this privilege of looking at the work of the person we go and interview. But I had this surprising and eye-opening encounter just there and then. Scrolling through their works, I noticed that in addition to making graffiti on the walls of Douma, they had done other work that documented revolutionary life in Syria. I 
was going through the pictures of graffiti and stumbled upon a colourful series of graffiti. I went through them and my gaze stopped and lingered on one particular work: that had a picture of a woman on it in bright colours and the string of words below the graffiti uttered: the revolution is feminine. I remember feeling such natural joy, my mind was racing and I read layers and layers of meaning on this work. I wondered whether the author was a feminist, and whether I would get an elaborate articulation of feminist aims and goals for the revolution. I read so much into it. Only to, at the interview (Personal communication, 30 April 2019), encounter:

Artist: I made this graffiti, in particular, to my girlfriend at the time, I wanted to impress her. Adding, that this series should be viewed for its colours. [A couple of days before when I had encountered his work on the wall of the café I immediately sensed the politics of suffering, noticing the colours, but somehow still locating them to the background]. There was an explicit attempt to introduce colours into this neighbourhood that was devastated and grey. It was meant to speak 'life. 10 Pushing me to recognise in practice what dialogic interviews are. They are about the engagement and sharing of knowledges, sitting with and listening to one another, without, of course, any guarantees for clarity, understanding (see Berlant 2011 on a properly political concept of love).

Ravecca and Dauphinée express something that we have vividly experienced and want to explore further, how we can and why we need to 'maintain the gesture of open-ended critique that lies in actively interpreting a text' (2018, 8). If fieldwork means that our insights spring from the many encounters we have, then it also means that these moments and their reverberations as they continue to affect us leave us with a well of insights that are imagined and created together. In the excerpt above, an instance of a dialogic encounter is captured: how we muddle through in trying to understand, demonstrating the

10 And only later, going through my notes, still holding on to the encounters had and what they taught me, I saw the word 'life' and was reminded by Rafeef Ziadah's (2011) poem 'We teach life, sir' where she pithily captures the arrogance of engagement that demands instead of listens (or as Pin-Fat $(2019,199)$ describes IR's ingrained attitude: 'the sovereign demand directed to the other to present their humanity in ways that the sovereign can recognise'): we don't need you to be preoccupied with how you see 'our violence' (please, turn to your own!), rather listen to our life stories in these circumstances. Having gone back to the interview and having it circle in my head with the rest of my interviews I saw two key patterns emerging: one to do with either the need or the conscious choice to emphasise that 'we are humans (not terrorists)' (something when uttered in my interviews left me with such shame) and the other to do with the strong emphasis put on life and humanity when they felt that their agency was being curtailed and/or their stories limited to certain themes. 
importance of cultivating a way of relating that sees learning from and listening to others as ongoing work. As we continue to think with the many people we encounter and think through our experiences, we are always reminded of the field-experiences from our previous encounters - not to mention all the relationships we sustain that shape us (see Austin, Bellanova and Kaufmann 2019) - that infuse and shape our present encounters. One of those fields is our academic home, or the lack thereof, that affects how we come to and what we learn from these encounters, and how we prepare for as well as 'write up' our encounters.

Relationality is a component that we actively seek out in our field encounters by the fieldwork choices we make, and how we come to understand what the 'field' even is (see Fujii 2017; Poopuu 2020; Inayatullah 2019). Even if we acknowledge the inescapability of the many relations, the question is, as Kurowska ponders, 'what to do with uninterpretable moments in fieldwork?' (2020a, 2). Combining narrative sensibility with the tools relational psychoanalysis provides, she carefully examines the mess that our analysis entails and 'the always partial and unstable character of interpretation' (ibid., 3; Page 2017). So doing, the ethical labour that fieldwork entails is presented anew so that we would be more prepared to work through together (Kurowska 2020a, 13). Both of us have done fieldwork in less traditional ways, where rather than studying in a specific location or with a community for an extended period of time, we have imagined multi-sited fields together with our research participants. Together we have started thinking also how our fieldwork stretches to and happens in the different spaces we live, especially at our universities. This has entailed, for example, fostering spaces of care, mutual support and understanding through fieldwork chats gatherings. This praxis institutes collegiality and thought-companionship, where the neoliberal university demands individual brilliance, effectiveness and speed, and thus erases space for voicing discomfort and unease.

This reflects contemporary and relational notions of fieldwork in which the 'field' is no longer something out there, awaiting discovery (Amit 2003), but instead something which we actively (co-)construct, and in so doing, which we are an integral part of. If our notions of ourselves as 'fieldworkers' are embedded in, affecting and impacted by our field sites and our fieldwork, it is important that we also take into account the relations and spaces we hold throughout our fieldwork processes. Hence fieldwork relations entail more than the way we relate to those we work with and encounter in our fields. Our fieldwork and fieldwork experience is also formed by our relations with our peers, colleagues, the literatures we engage with, and our own life stories (Neumann and Neumann 2015; Austin, Bellanova, and Kaufmann 2019). All this means that 
our encounters are always connected to and embedded in other encounters that impact the most immediate ones.

How relations are established can be an important part of the fieldwork process, as often they happen in unplanned ways. Although most researchers start out with some ideas of fieldwork they are conducting and with whom, including ideas about participant observation, interviewing, participatory or collaborative research designs, they can never fully grasp how relationships form in and beyond the field.

Suzanne Klein Schaarsberg's piece on contemplative activism thoughtfully engages with her research participants and ponders how our positionalities and our worlds shift and change as we paradoxically both move and stop and see in our fields. Her writing respects how we are part of multiple relations and how in many ways parts of these relationships remain beyond our grasp. By urging us to trust the reality of other people even if we cannot understand it (see Pin-Fat 2019), she turns to a practice of 'yes, perhaps' which demands openness to experiential knowing without the certainty of finding answers. Through this exercise she shows that there is continuous (un)learning in the field and her praxis of 'yes, perhaps' - 'to stop and see different things' - allows us to trouble how and what we see.

\section{Collaboration}

Reflecting on relations and relationality then brings us to the role of collaboration: to what extent can and should we collaborate with those that inform our research, those that we interview or engage with in our fields? And how can collaboration be fostered throughout the fieldwork process, including our preparations for fieldwork and our interpretation of and writing about our collected 'data'? We believe the latter can be a helpful element in making us better equipped to prepare for fieldwork's messiness, and unexpectedness, and can be fruitful ground for thinking through our experiences and ideas with others as part of fieldwork fluency.

We have experienced collaboration and exchange as an important part of our learning process - as we reflected, some of our collective experiences of exchange and organised chats around fieldwork not only gave us support but sparked the very idea for this running theme. Actively making room for and seeking out collaboration and peer support can also counter the individualising tendencies that are experienced in neoliberalising universities. ${ }^{11}$ To work

11 Mountz et al. (2015) have compiled a helpful list of ideas of how to practice 'care-full' work. What they stress is that slow scholarship is as much about self-care as it is about care for your many relations and collective action to change the university culture. 
together and make room for an exchange of experiences and reflections can then be an act of challenging contemporary academia's culture of speed:

Slowing down is about asserting the importance of contemplation, connectedness, fruition, and complexity. It gives meaning to letting research take the time it needs to ripen and makes it easier to resist the pressure to be faster (Berg and Seeber 2016, 57; see also Mountz et al. 2015).

If we make collaboration an important part of our fieldwork process, we see how as peers we can create a 'holding environment' (Martela 2014, 85; Berg and Seeber 2016). Such a holding environment not only makes our research less individualistic, it also offers a space for thinking together, to articulate and share experiences, support, recognition and care. This running theme offers a space for such reflections.

What does it mean to engage in different kinds of research relationships? One of the ethical questions at the heart of fieldwork concerns our relationship to our interlocutors. ${ }^{12}$ There is no clear-cut answer that offers a template how these relationships should work: there is, however, a necessity to think through the many forms these collaborations can take before engaging in research as well as the need to continually reflect on them. Our starting points for research matter greatly (are we committed to imagine the world anti-colonially, see Rutazibwa 2020): Are we prepared, as Haraway asks us $(2016,2)$, to 'stay with the trouble of living and dying in response-ability on a damaged earth', that is, are we prepared to question where and with whom we start and how we operate, as:

It matters what matters we use to think other matters with; it matters what stories we tell to tell other stories with ... It matters what stories make worlds, what worlds make stories. (Haraway taking inspiration from Marilyn Strathern's thinking, 2016, 12) ${ }^{13}$

For example, aware of the fact that the disciplines in which we are trained can inflict epistemic violence (e.g., as is the case with IR: Smith and Tickner 2020;

12 There are a number of ethical considerations to bear in mind when doing fieldwork, not all of them are listed here, for insightful resources start with all the contributions across this running theme that from different standpoints reflect on diverse issues, but also consult the many other imaginative works referenced within this introduction (see also the collaborative syllabus on research ethics maintained by Rodehau-Noack and the ARC bibliography for research ethics in violent contexts).

13 See also Dauphinée (2007, 40-45); and Kurowska (2019, 81). 
Kamola 2020; Rutazibwa 2020), we have openly worked at cultivating a decolonial and feminist research ethic (Ackerley and True 2008; Odysseos 2017; Tucker 2018; Gunaratnam and Hamilton 2017) that is attuned to the politics of our research process. This gives us the groundwork from which we are able to see the world in more plural terms, of being aware that we only ever operate with incomplete knowledge (see Weber 2017). In particular, from this position we are able to take seriously the many relationships we are and become part of. Importantly, our starting points provide us with the lenses to see plural worlds. If our starting points also admit that we are situated and our knowledge is only ever incomplete, the more room for manoeuvre we have to create and leave space for other viewpoints, for changing our approach, and perhaps not fretting to do this in the midst of our projects. So our starting points greatly structure how we come to think about our research relationships in the first place.

Collaborating, or working, with our interlocutors can take many forms, such as practising relational interviews (Fujii 2017) which take seriously the meanings and stories of our conversation partners and which foster openness and critique as to where we place and how we negotiate interpretative authority (Fobear 2016; Kurowska 2020a). We can imagine starting to formulate our research question and design together with our research participants as is common to community-based critical participatory action research, but also manifold other ways of practising research in collaborative terms (Bliesemann de Guevara, Furnari, and Julian 2020; Močnik 2018; Pittaway, Bartolomei, and Hugman 2010; Tilley 2017; Torre et al. 2018; Fine 2016; Tuhiwai Smith 2012; Squire et al. 2021). Engaging in decolonial knowledge production problematises how we create room for our researched and entails constant negotiation of the researched-researcher relationship (Tilley 2017; Pittaway, Bartolomei, and Hugman 2010; Andreotti 2016), ${ }^{14}$ and reflects on the challenges that collaborative research involves, how it is marked by many stumbling blocks and how we can potentially overcome these (see Poets 2020; Bouka 2018).

We suggest here that there is no one way to negotiate collaboration but what is needed is to make the route taken transparent and reflect on why, how it worked out (esp., since our many relations and fields affect us), so that others can discuss and learn with and from us (Pachirat 2017). Gemma Bird and Liska Bernet do just that, they engage in a conversation where they reflect back on their praxis of collaboration, and how this has developed in dialogue with the literature on Indigenous scholarship, working together, and individual and

14 We need also to bear in mind the situationally relevant power imbalances when we envisage these relationships. These issues are discussed in a very experience-near way in the following works: Mwambari (2019), Tilley (2017). 
joint reflection. Keeping in sight the many fields from which their engagement begins they tease out relevant issues that greatly affect how we imagine and are able to practice fieldwork. To negotiate how to navigate this terrain of powerful fields structuring our praxis they turn to solidarity. For them solidarity stands for 'opening up dialogues about what works for different people' as well as envisaging their partnership through a lens of shared humanity which extends from immediate help to structural change. Thus, they imagine their collaboration through 'ongoing dialogue and reciprocity'.

One of the intriguing questions that has been recently reimagined, touches upon the methods used to relate to our research participants. Fieldwork commonly refers to participant observation and interviews, and conversations, but many scholars have made a case that we should be open to more diverse repertoires of engagement because they allow us to access knowledge that might not be available through traditional methods and/or solely with them. Furthermore, it refers to a praxis of co-production that a researcher arrives at in conversation with our interlocutors (Vastapuu 2018; Harman 2019; Močnik 2018; Andrä et al. 2020). Omer Aijazi asks us: 'Is foraging the forest for food, cooking, and eating with your interlocutors a mode of fieldwork?' It is for our readers and wider companions in our academic house to decide, nonetheless, Aijazi takes us on a journey where food becomes the medium through which everyday violence gets felt and snapshots of life-worlds around food are left with us. The piece asks about the purpose of our research, exploring where our research should take us, if it should take us somewhere at all? With an eye to the value and promise of knowing differently, Maria-Adriana Deiana ponders and troubles the usual texts through which we come to know our research participants and their life-worlds. Through reflecting what the reading of the novel Milkman by Anna Burns made her feel, she complicates assumptions that see fieldwork as an 'accumulative acquiring of knowingness' and proposes that it is through aesthetic narratives that we are faced with the messiness of knowing conflict.

As Indigenous, feminist, queer, decolonial and postcolonial scholars and activists have said (Causevic et al. 2020), our research partnerships should speak to our practices within academia too: how can we practice solidarity in our institutional and political environments? Would this be one way of co-imagining ethical fieldwork encounters that build on communion (the cultivation of respectful relations) and based on answering: what do we owe to our research participants? All this said, we have taken note how the ongoingness of all the above means it is fraught with constant figuring out - we never once and for all imagine and work with our interlocutors, it is ongoing work. We might think we make a plan and follow, but it is a lived experience of constant negotiation and re-thinking. We change, grow, learn along the way, which 
means that there is a contextual journey we live during our research that we cannot really prepare ourselves for. Critically, often it is the work we do contextually with many others that shifts our ways of seeing.

As part of this contextual journey, our ideas of participation also develop and change. As Silvia Hassouna reflects in this issue, participation can be learned and unlearned, as we negotiate the different positionalities we embody and are perceived to embody in the field. Rather than shying away from our own investments in the field research, or navel-gazing on our own identity and positionality, Hassouna suggests that we can make the links between our 'personal and intellectual motivations' more explicit. Dwelling on our own emotional investments can help in positioning ourselves, and help us arrive at a more responsible research practice. When we do so we can see that our vulnerabilities in the field can also offer new insights and that engagement with and participation in 'the field' is a 'life-time project'.

\section{Ongoingness}

Knowing that we run against and confront our academic home - even as we make choices to follow certain perhaps more emancipatory and caring theories such as decolonial and feminist approaches - we run into the wider scaffolds of our disciplines that house disciplinary frames and material structures that severely limit, restrict, and force us to be creative to keep unlearning those aspects that do harm. ${ }^{15}$ This is illustrated by Elena Stavrevska and Maja Nenadovic in this running theme, who, in their contribution, reflect on the need to unlearn parts of our academic upbringing to be able to (re)learn how to research one's home. Researching contexts once familiar can create productive tensions that make us more aware of 'the liberal and colonial undertones' of academic fields, such as peace and conflict studies, and critically interrogate how academic backgrounds can limit us and our vocabularies in the field.

Ongoingness, or fieldwork as a process, does not necessarily mean that fieldwork is always in motion, or moving in a way that we can perceive. Sometimes it can precisely be that fieldwork makes us stand still, pauses us, and such a slower pace can make us attentive to new experiences and insights. Dagmar Rychnovska writes about having feelings of unease and discomfort even

15 Even if, as Smith and Tickner note, 'a growing "decolonializing" mood is permeating the IR discipline' and 'doing IR "differently" has become increasingly embraced' it seems that 'deeply entrenched disciplinary logics' still find their way into our praxis (e.g., syllabi), and thus limit our students' imaginations, and the actual ways of how to practise this 'differently' continue to animate our debates $(2020,1-2)$. In our everyday practices within our academic fields we are parties to actively or passively constructing these fields, and thus need to openly engage with this issue (the wider questions surrounding this are carefully unpacked by Kamola 2020). 
though the fieldwork was in theory going extremely well, coming to the realization that living with one's positionality and privileges in the field comes with 'new dimensions of responsibility'. Pausing in the field, or encountering field experiences that make one pause, can be great opportunities for learning. When slowing our pace in the field we can come to appreciate the seemingly 'boring, parochial and "small"' things we encounter, in fact, might be able to tell us a great deal about 'the "big world" of the international'.

What are the aspects of ongoingness that matter most to us? Envisaging fieldwork as non-linear and open framework as well as process (Cerwonka and Malkki 2007) means that as researchers we continuously go back and forth: 'Aha!' moments braided with experienced failures, surprises, and our own 'gut feeling' of what next steps may be. If fieldwork is non-linear, can you ever be prepared? Does ongoing sharing of experience help and equip us better in our fieldwork praxis? How can we more carefully and collectively continue the necessary (field)work at 'home'?

\section{Ethics in motion}

It is true that our ethical considerations need to start from thinking through what we can learn from literature, our peers and colleagues, but they also need to entertain an openness to contextually negotiating and figuring out with our multiple companions in research. For us, this process of becoming fluent in fieldwork entails negotiating and making decisions about what is good/ethi$\mathrm{cal} /$ responsible research, and how to navigate tensions between possible definitions (e.g. Ackerly and True 2008; Adedi Dunia et al. 2019; Kurowska 2020a; Pachirat 2017). Generally speaking, the continuum of ethical fieldwork runs from minimalistic compliance with institutional guidelines to approaches that demand a commitment to 'work with' research participants, and engagements with a feminist ethics of care as principles of good fieldwork (Bliesemann de Guevara, Furnari and Julian 2020; Browne and Moffett 2014; Chatterton, Fuller, and Routledge 2007; Krystalli 2021; Lawson 2009; Močnik 2018; Nagar 2014; Poopuu 2020; Refstie 2018; Torre et al. 2018; Wibben 2016). Engaging with these challenges, contributors present reflexive and ongoing journeys that contribute to our understanding of academic, individual and collective efforts to negotiate research ethics, practices of communal care and our praxis with the priorities and demands of higher education institutions.

Taking into account these plural definitions and practices of fieldwork ethics, also indicates that doing ethical fieldwork is a process that spans the period before, during and after the fieldwork. Navigating ethical challenges is then also an ongoing process, of trusting one's gut feeling, navigating possible tensions in continuous ways. Wen-Yu Wu in this running theme reflects on the role of money in field research - a question that is often reflected 
upon merely in terms of what it means for the researcher: the ability to travel, or to do fieldwork in a particular way, or the intricacies of getting fieldwork funding for certain projects and not others. But money also plays a big role as an ongoing feature in the relationships that researchers build with their research participants. As Wu reflects, the affluent position of a funded researcher can, especially in more precarious contexts, stand in stark contrast to local populations and research participants, and can explicate power differences and relations. Wu describes her experiences of navigating ethical questions this has brought up, such as 'who pays the bill?' during fieldwork. And how do you, as a researcher, deal with money issues in the field when your participants may have very little?

Mariam Salehi's account of doing fieldwork in Tunisia presents her ongoing efforts in working through ethical dilemmas contextually. She visibilises her own sharp learning curve in the field, both as her research participants challenged her to re-think her focus and how she needed to make practical judgment calls with reference to safety issues that she was inadequately prepared for by her academic institution. While reflecting on her journey two pivotal aspects are highlighted, one to do with time and timing - the ways in which recurrent changes in context shaped her work - and the other to do with the ongoingness of negotiating and learning while in the field and how this learning perhaps sharpens our fieldwork sensibility for future research.

By perceiving and positioning fieldwork as a continuous process in which we constantly work at our praxis, research ethics does not only have an impact in terms of who we study (with) and how. But it also helps to critically interrogate the ways in which, each time we approach fieldwork, we learn and unlearn together with our research participants/associates, from our past and others' praxis. Therefore, becoming fluent in fieldwork represents a reflexive and ongoing journey where together with many others we negotiate research ethics and our praxis. As the contributions to this running theme and the illuminating experience-near fieldwork accounts referenced throughout this introduction exemplify, continuous work and (un)learning together with many others goes into practising research that is ethical.

\section{Conclusion}

Radical tenderness ... is to find a galaxy in the eyes of another \& not break the gaze. $^{16}$

16 Radical tenderness is a living manifesto written by Dani D’Emilia and Daniel B. Chávez (2015) and to us it speaks of the need to cultivate ethical encounters in an ongoing fashion. 
This running theme asks us to consider what changes or must change in our praxis of fieldwork when we imagine fieldwork as a continuous process together with many others and as necessarily relational. We have silhouetted some of the key features of becoming fluent in fieldwork, in particular highlighting the ongoingness of it and the sharing and collaboration involved. These features, combined with a focus on relations, relationality and ethics in motion, allow us to work towards seeing plural worlds. Rather than imposing our views as researchers under the guise of 'situatedness', the praxis of relationality recognises that those we research with bring with them 'views from different worlds, rather than perspectives about the same world' (de la Cadena 2010, 351). Bringing relationality, ongoingness, collaboration and a sense of ethics in motion to our fieldwork exposes the politics of our work and teases out contextual relational moments of figuring out - e.g., how we understand collaboration and how it shifts in motion. Being inspired by Minna Salami's account of what sensuous knowledge is, we are in full agreement that ongoingness together hints at:

perceiving knowledge as a living and breathing entity rather than as a packaged product to passively consume. It is encountering knowledge as a partner rather than a servant - or as a lord, for that matter. (Salami 2020, 15)

If we think in collaborative terms contextually: what does it mean for our institutional frames that more often than not see research as an individual endeavour? What does it mean to continuously negotiate our research design as we (un)learn when moving between and with fields? If we work together with our research participants what does it mean to ask what this research means to us both, researcher and research participant? Iteratively practising fieldwork leaves us with all the hard work that goes into preparation but simultaneously all the efforts that go into constant negotiations of the parameters set as we move together. Lastly, sharing experience - a recurrent motif that has helped us to cope with a wide range of emotions and questions our fieldwork projects have engendered - works as an imaginative space that can better prepare and support us when taking on the journey of fieldwork.

This introduction captures our own ruminations of what this constant process of becoming fluent in fieldwork might entail. In the process of writing this we have been in continuous engagement with the ideas and experience of all our contributors. If we have crafted an open-ended conversation that asks more than it is able to answer, then our contributors' pieces bring the needed nuance, offering contextual experiences of what it means to become fluent. As the array of contributions in this running theme highlight, carrying a feeling 
of unease or discomfort can be instructive (even if at times filling us with anxiety) because it pushes us into conversations, explorations, (un)learning, even experiments of thinking and doing differently. For the two of us, it has been about ongoing conversations talking through how we travel between fields, and at the same time with fields, and why the academic field, which claims to equip us with knowledge and tools, so often escapes our sight, invisibilising the structures, thought-patterns and instructions it asks us to take on board. This running theme extends this questioning beyond static spaces and times to interrogate the ways in which fields interlace, speak to and see one another. What happens when we seriously interrogate how the fields we inhabit are entangled? If our methods together with the research routes supported by our academic homes imagine worlds, and we thus participate in building worlds, what is our responsibility?

\section{Acknowledgements}

Birgit Poopuu would like to acknowledge that on her end this work was supported by the Estonian Research Council grant (MOBTP20o).

\section{References}

Ackerly, Brooke, and Jacqui True. 2008. "Reflexivity in Practice: Power and Ethics in Feminist Research on International Relations." International Studies Review, 10 (4), 693-707.

Adedi Dunia, Oscar et al. 2019. "Moving Out of the Backstage: How Can We Decolonize Research." The Disorder of Things, 22 Oct. 2019, https://thedisorderofthings. com/2019/10/22/moving-out-ofthe-backstage-how-can-we-decolonize-research/\#_ ednref3.

Amit, Vered, ed. 2003. Constructing the Field: Ethnographic Fieldwork in the Contemporary World. Routledge.

Andreotti, Vanessa. 2016. "Multi-layered Selves: Colonialism, Decolonization and Counter-intuitive Learning Space." Arts Everywhere-Musagetes, http:// artseverywhere.ca/2016/10/12/multi-layered-selves/\#_ednref3.

Andrä, Christine, Berit Bliesemann de Guevara, Lydia Cole, and Danielle House. 2020.

"Knowing through Needlework:Curating the Difficult Knowledge of ConflictTextiles." Critical Military Studies 6 (3-4):341-359. doi: 10.108o/23337486.2019.1692566.

Aradau, Claudia, and Jef Huysmans. 2014. "Critical Methods in International Relations: The Politics of Techniques, Devices and Acts." European Journal of International Relations 20 (3): 596-619. 
ARC Bibliography. Ongoing. "The Advancing Research on Conflict (ARC) Bibliography." https://advancingconflictresearch.com/resources-1.

Austin, Jonathan Luke, Rocco Bellanova, and Mareile Kaufmann. 2019. "Doing and Mediating Critique: An Invitation to Practice Companionship." Security Dialogue $5^{\circ}(1): 3^{-19}$.

Berg, Maggie, and Barbara K. Seeber. 2016. The Slow Professor: Challenging the Culture of Speed in the Academy. University of Toronto Press.

Berlant, Lauren. 2011. "A properly political concept of love: Three approaches in ten pages." Cultural Anthropology 26 (4): 683-691.

Bhandar, Brenna and Rafeef Ziadah, eds. 2020. Revolutionary Feminisms. Verso.

Bliesemann de Guevara, Berit, and Morten Bøås, eds. 2020. Doing Fieldwork in Areas of International Intervention. Bristol University Press. Kindle Edition.

Bliesemann de Guevara, Berit, Ellen Furnari, and Rachel Julian. 2020. "Researching with 'Local' Associates: Power, Trust and Data in an Interpretive Project on Communities' Conflict Knowledge in Myanmar." Civil Wars. doi:10.108o/13698249.2020.1755161.

Bouka, Yolande. 2018. "Collaborative Research as Structural Violence." Political Violence at a Glance. https://politicalviolenceataglance.org/2018/o7/12/collaborativeresearch-as-structural-violence/.

Browne, Brendan, and Luke Moffett. 2014. "Finding Your Feet in the Field: Critical Reflections of Early Career Researchers on Field Research in Transitional Societies." Journal of Human Rights Practice 6 (2): 223-237.

de la Cadena, Marisol. (2010) "Indigenous cosmopolitics in the Andes: Conceptual reflections beyond 'politics." Cultural anthropology 25.2 (2010): 334-370.

Carabelli, Giulia, and Maria Adriana Deiana. 2019. "Researching in Proximity to War. A Love Story." Journal of Narrative Politics 5 (2): 91-101.

Causevic, Az, Kavita Philip, Maari Zwick-Maitreyi, Persephone Hooper Lewis, Siko Bouterse \& Anasuya Sengupta. 2020. "Centering Knowledge from the Margins: Our Embodied Practices of Epistemic Resistance and Revolution." International Feminist Journal of Politics 22 (1): 6-25. DOI: 10.1080/14616742.2019.1701515.

Cerwonka, Allaine, and Liisa H. Malkki. 2007. Improvising Theory: Process and Temporality in Ethnographic Fieldwork. Chicago: University of Chicago Press.

Chatterton, Paul, Duncan Fuller, and Paul Routledge. 2007. "Relating Action to Activism: Theoretical and Methodological Reflections." In Participatory Action Research Approaches and Methods: Connecting People, Participation and Place, edited by Sara Kindon, Rachel Pain and Mike Kesby, 216-222. Routledge.

Chatterton, Paul, Stuart Hodkinson, and Jenny Pickerill. 2010. "Beyond Scholar Activism: Making Strategic Interventions Inside and Outside the Neoliberal University." Acme $9(2): 245^{-275}$.

Daigle, Megan D. 2015. From Cuba with Love: Sex and Money in the Twenty-first Century. University of California Press. 
Dauphinée, Elizabeth. 2007. The Ethics of Researching War: Looking for Bosnia. Manchester University Press.

D’Emilia, Dani, and Daniel B. Chávez. 2015. "The Radical Tenderness Manifesto." https://danidemilia.com/radical-tenderness/.

Eliasoph, Nina. 2005. "Theorizing from the Neck Down: Why Social Research Must Understand Bodies Acting in Real Space and Time (and Why It's So Hard to Spell Out What We Learn from This)." Qualitative Sociology 28 (2): 159-169.

Eriksson Baaz, Maria, and Maria Stern. 2016. "Researching wartime rape in the Democratic Republic of Congo: A methodology of unease." In Researching War, edited by Annick T.R. Wibben, 117-140. Routledge.

Evans, Mel, Emma Hughes and Ruth Potts. 2021. "The Making of Critical Knowledge Claims: Research, 'Allyship' and Politics of Representation." Discover Society: New Series 1 (3).

Ewing, Eve L. 2019. "Interview with Mariame Kaba: Everything Worthwhile Is Done With Other People." Adi Magazine. https://adimagazine.com/articles/mariamekaba-everything-worthwhile-is-done-with-other-people/?fbclid=IwAR3-SUVThzNl anokpU8R8Q70C1zS1H39LoJzHx2TN7LLbKoPVAlkedmSnXQ.

Fine, Michelle. 2016. "Just methods in revolting times." Qualitative research in psychology $13(4): 347-365$.

Fobear, Katherine. 2016. "Do You Understand? Unsettling Interpretative Authority in Feminist Oral History." Journal of Feminist Scholarship 10 (10): 61-77.

Fujii, Lee Ann. 2017. Interviewing in Social Science Research: A Relational Approach. Routledge.

Goffman, Alice. 2014. On the Run: Fugitive Life in an American City. University of Chicago Press.

Gunaratnam, Yasmin, and Carrie Hamilton. 2017. "Introduction the Wherewithal of Feminist Methods." Feminist Review 115 (1): 1-12.

Günel, Gökçe, Saiba Varma, and Chika Watanabe. 2020. "A Manifesto for Patchwork Ethnography." Member Voices, Fieldsights, June 9. https://culanth.org/fieldsights/ a-manifesto-for-patchwork-ethnography.

Haraway, Donna J. 2016. Staying with the Trouble: Making Kin in the Chthulucene. Duke University Press.

Harman, Sophie. 2019. Seeing politics: film, visual method, and international relations. McGill-Queen's Press.

hooks, bell. 2002. Communion: The female search for love. Perennial.

Inayatullah, Naeem. 2019. "Why Do Some People Think they Know What Is Good for Others?" In Global Politics: A New Introduction (third edition), edited by Jenny Edkins and Maja Zehfuss, 344-369. Abingdon: Routledge.

Kamola, Isaac. 202O. "IR, the Critic, and the World: From Reifying the Discipline to Decolonising the University." Millennium. https://doi.org/10.1177/o305829820937063. 
Kaczmarska, Katarzyna. 2020. Making Global Knowledge in Local Contexts: The Politics of International Relations and Policy Advice in Russia. Routledge.

Krystalli, Roxani C. 2021. "Narrating victimhood: dilemmas and (in)dignities." International Feminist Journal of Politics. doi: 10.108o/14616742.2020.1861961.

Kurowska, Xymena. 2019. "When one Door Closes, Another One Opens? The Ways and Byways of Denied Access, or a Central European Liberal in Fieldwork Failure." Journal of Narrative Politics 5(2): 71-85.

Kurowska, Xymena. 2020a. "Interpreting the Uninterpretable:The Ethics of Opaqueness as an Approach to Moments of Inscrutability in Fieldwork." International Political Sociology.

Kurowska, Xymena. 202ob. "The Secondary Gains of Neoliberal Pain: The Limits of Consolation as a Response to Academic Anguish." Political Anthropological Research on International Social Sciences (PARISS) 1 (1): 117-136. https://doi. org/10.1163/25903276-bja1ooo2.

Kušić, Katarina, and Jakub Záhora, eds. 2020. Fieldwork as Failure: Living and Knowing in the Field of IR. E-IR Publishing.

Lawson, Victoria. 2009. “Instead of Radical Geography, How About Caring Geography?" Antipode 41 (1): 210-213.

Ling, L. H. M. 2017. “Don’t Flatter Yourself: World Politics as We Know It Is Changing and so Must Disciplinary IR." In What's the Point of International Relations?, edited by Synne L. Dyvik, Jan Selby and Rorden Wilkinson, 135-146. Routledge.

Lisle, Debbie. 2016. "Waiting for International Political Sociology: A Field Guide to Living In-between." International Political Sociology 10 (4): 417-433.

Lowe, Lisa. 2020. "Afterword: Revolutionary Feminisms in a Time of Monsters." In Revolutionary Feminisms, edited by Brenna Bhandar and Rafeef Ziadah, 217-227. Verso.

Mac Ginty, Roger, Vogel, Birte, and Brett, Roddy, eds. 2020. Companion to Conducting Field Research in Peace and Conflict Studies. Palgrave.

Martela, Frank. 2014. "Sharing Well-being in a Work Community-Exploring Wellbeing-generating Relational Systems". In Emotions and the Organizational Fabric (Research on Emotion in Organizations, Volume 1o). Edited by Ashkanasy, Neal M., Wilfred J. Zerbe, and Charmine EJ Härtel. Emerald Group Publishing Limited.

Močnik, Nena. 2018. Sexuality after War Rape: From Narrative to Embodied Research. Routledge.

Močnik, Nena, and Ahmad Ghouri, ed. 2020. "The Cost of Bearing Witness: Secondary Trauma and Self-Care in Fieldwork-Based Social Research." Social Epistemology (special issue) 34 (1): 1-100.

Mountz, Alison, Anne Bonds, Becky Mansfield, Jenna Loyd, Jennifer Hyndman, Margaret Walton-Roberts, Ranu Basu, Risa Whitson, Roberta Hawkins, Trina Hamilton and 
Winifred Curran. 2015. "For Slow Scholarship: A Feminist Politics of Resistance through Collective Action in the Neoliberal University." ACME 14 (4): 1235-1259.

Mwambari, David. 2019. "Local Positionality in the Production of Knowledge in Northern Uganda." International Journal of Qualitative Methods. https:/doi. org/10.1177/16o9406919864845.

Nagar, Richa. 2014. Muddying the Waters: Coauthoring Feminisms Across Scholarship and Activism. University of Illinois Press.

Neumann, Cecilie Basberg, and Iver B. Neumann. (2015). "Uses of the self: Two ways of thinking about scholarly situatedness and method." Millennium 43 (3): 798-819.

Odysseos, Louiza. 2017. "Prolegomena" to any Future Decolonial Ethics: Coloniality, Poetics and 'Being Human as Praxis.' " Millennium: Journal of International Studies $45(3): 447-472$.

Olufemi, Lola. 2020. Feminism, Interrupted:Disrupting Power. Pluto Press.

Pachirat, Timothy. 2017. Among Wolves: Ethnography and the Immersive Study of Power. Routledge.

Page, Tiffany. 2017. "Vulnerable Writing as a Feminist Methodological Practice." Feminist Review 115 (1), 13-29. https://doi.org/10.1057/s41305-017-0o28-o.

Perera, Suda. 2017. "Bermuda Triangulation: Embracing the Messiness of Researching in Conflict." Journal of Intervention and Statebuilding 11 (1):42-57.

Personal communication, 30 April 2019, Beirut, Lebanon.

Pin-Fat, Véronique. 2019. “' 'What's Love Got to Do with It?' Ethics, Emotions, and Encounter in International Relations." Review of International Studies 45 (2):181-200.

Pittaway, Eileen, Linda Bartolomei, and Richard Hugman. 2010. "'Stop Stealing Our Stories': The Ethics of Research with Vulnerable Groups." Journal of Human Rights Practice 2 (2): 229-251.

Poets, Desiree. 2020. "Failing in the Reflexive and Collaborative Turns: Empire, Gender and the Impossibilities of North-South Collaborations". In Fieldwork as Failure: living and knowing in the field of IR, edited by Katarina Kušić and Jakub Záhora. E-IR Publishing.

Poopuu, Birgit. 2020. "Dialogical Research Design: Practising Ethical, Useful and Safe(r) Research." Social Epistemology 34 (1): 31-42.

Ravecca, Paulo, and Elizabeth Dauphinée. 2018. "Narrative and the Possibilities for Scholarship." International Political Sociology 12 (2):125-138. https://doi.org/10.1093/ ips/olxo29.

Refstie, Hilde. 2018. "Action Research in Critical Scholarship: Negotiating Multiple Imperatives.” ACME: An International Journal for Critical Geographies 17 (1): 201-227.

Rodehau-Noack, Johanna. Ongoing. "Collaborative Syllabus on Ethics in Conflict Research.” https://docs.google.com/document/d/1WzK6P5boWsWOgmdFW8 fwDA8-ccIntWoC3AxHZcWOCXI/edit. 
Rutazibwa, Olivia. 2020. "Hidden in Plain Sight: Coloniality, Capitalism and Race/ism as Far as the Eye Can See." Millennium 48 (2): 221-241.

Salami, Minna. 2020. Sensuous Knowledge: A Black Feminist Approach for Everyone. Zed Books.

Smith, Karen, and Arlene B. Tickner. 2020. "Introduction: International Relations from the global South." In International Relations from the Global South: Worlds of Difference, edited by Arlene B. Tickner and Karen Smith, 1-14. Routledge.

Squire, Vicki, Nina Perkowski, Dallal Stevens, ja Nick Vaughan-Williams. 2021 Reclaiming migration: voices from Europe's 'migrant crisis'. Manchester University Press.

Tilley, Lisa. 2017. "Resisting Piratic Method by Doing Research Otherwise." Sociology $5^{1}$ (1): $27-42$.

Torre, M. E, Stoudt, B. G., Manoff, E. and M. Fine. 2018. "Critical Participatory Action Research on State Violence: Bearing Wit(h)ness across Fault Lines of Power, Privilege and Dispossession," in The Sage Handbook of Qualitative Research (5th edition), edited by N. K. Denzin and Y. S. Lincoln, 492-515. Sage Publications.

Tucker, Karen. 2018. "Unraveling Coloniality in International Relations: Knowledge, Relationality, and Strategies for Engagement." International Political Sociology 12 (3): $215^{-232 .}$

Tuhiwai Smith, Linda. 2012. Decolonizing Methodologies: Research and Indigenous Peoples, second edition (Kindle). Zed Books.

Vastapuu, Leena. 2018. Liberia's Women Veterans: War, Roles, Reintegration. Zed Books. Weber, Cynthia. 2017. "What's the Point of IR?: Or, We're so Paranoid, We Probably Think This Question is about Us." In What's the point of International Relations?, edited by Synne L. Dyvik, Jan Selby, Rorden Wilkinson. 46-56. Routledge.

Wibben, Annick T. R., ed. 2016. Researching War: Feminist Methods, Ethics and Politics. Routledge.

Wilkinson, Cai. 2015. "Not Just Finding What You (Thought You) Were Looking for: Reflections on Fieldwork Data and Theory." In Interpretation and Method:Empirical Research Methods and the Interpretive Turn, edited by Dvora Yanow and Peregrine Schwartz-Shea, 387-405. Routledge.

Ziadah, Rafeef. 2011. 'We Teach Life, Sir'. YouTube video, London. https://www.youtube. com/watch?v=aKucPhgxHtM. 